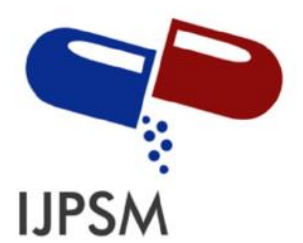

Lukkad Harish R et al, Int. Journal of Pharmaceutical Sciences and Medicine (IJPSM),

Vol.6 Issue. 4, April- 2021, pg. 52-66

ISSN: 2519-9889

Impact Factor: $\mathbf{3 . 4 2 6}$

\title{
FORMULATION AND EVALUATION OF MODIFIED DISINTEGRATING SUSTAINED RELEASE TABLETS OF DICLOFENAC SODIUM
}

\author{
Lukkad Harish R*; Oswal Rajesh \\ *Research Scholar \\ Shri Jagdish Prasad Jhabarmal Tibrewala University, Jhunjhunu, Rajasthan \\ DOI: 10.47760/ijpsm.2021.v06i04.005
}

*Corresponding author:

Harish R Lukkad

Email: harish_lukkad86@rediffmail.com

Mob: 9028787359

\begin{abstract}
Oral drug delivery is the largest and the oldest segment of the total drug delivery market. It is the fastest growing and most preferred route for drug administration. In oral drug delivery, the sustained release (SR) tablets maintains the desired drug concentration for prolong period of time, reduced 'see- saw' fluctuation, reduced total dose, improved efficiency in treatment. But many patients like paediatric, geriatric and also patients may have difficulty in swallowing (Dysphagia) find it difficult to swallow tablets and thus do not comply with prescription. This problem is overcome by formulating and developing modified disintegrating sustained release tablets. In this case, first microspheres of the drug are formulated by using any suitable technique. And then optimized microspheres formulation is further formulated in to the fast disintegrating tablets (FDT) by using superdisintegrants. So that after taking such a tablets, the tablet only disintegrates into the mouth then microspheres are separated and ingestion of such microspheres starts releasing drug for prolonged period of time. This concept fulfills both the advantages of sustained release and fast disintegrating tablets.
\end{abstract}

KEYWORDS: Oral drug delivery, Sustained release (SR) tablets, Fast disintegrating tablets (FDT), Microspheres, Superdisintegrants. 


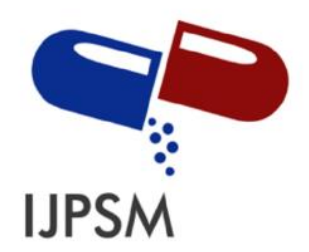

Lukkad Harish R et al, Int. Journal of Pharmaceutical Sciences and Medicine (IJPSM), Vol.6 Issue. 4, April- 2021, pg. 52-66

ISSN: 2519-9889

Impact Factor: $\mathbf{3 . 4 2 6}$

\section{INTRODUCTION}

Oral drug delivery is the most desirable and preferred method of administering therapeutic agents for their systemic effects. In addition, the oral medication is generally considered as the first avenue investigated in the discovery and development of new drug entities and pharmaceutical formulations, mainly because of patient acceptance, convenience, and cost effective manufacturing process. For many drug substances, conventional immediate release formulations provide clinically effective therapy while maintaining the required balance of pharmacokinetic and pharmacodynamic profiles with acceptable level of safety to the patient [1]. In recent years a wide variety of newer oral drug delivery systems like sustained/controlled release dosage forms are designed and evaluated in order to overcome the limitations of conventional therapy. These products are able to maintain steady drug plasma levels for extended periods of time, reduced total dose, improved efficiency in treatment as a result the variations of the drug levels in the blood are prevented and minimized drug related side effects [2,3]. But many patients like paediatric, geriatric and also patients may have difficulty in swallowing (Dysphagia) find it difficult to swallow tablets and thus do not comply with prescription. This problem is overcome by formulating and developing modified disintegrating sustained release tablets.

Microspheres is well accepted formulation employed to sustain the drug release and reduce or/ eliminate gastrointestinal irritation, dose intake and ultimately improve the compliance in the pharmacotherapy of arthritis, inflammation and pain [4,5]. United States Food and Drug Administration (FDA) defined FDT as "A solid dosage form containing medicinal substances or active ingredient which disintegrates rapidly usually within a matter of seconds when placed upon the tongue." FDT has several advantages like beneficial for travelling patients, easy to administered for geriatric, paediatric patients, excellent mouth feel property, beneficial for

patients may have difficulty in swallowing (Dysphagia), no need of water [6]. In this case, first microspheres of the drug are formulated by using any suitable technique. And then optimized 


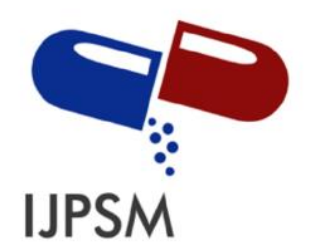

Lukkad Harish R et al, Int. Journal of Pharmaceutical Sciences and Medicine (IJPSM), Vol.6 Issue. 4, April- 2021, pg. 52-66

ISSN: 2519-9889

Impact Factor: $\mathbf{3 . 4 2 6}$

microspheres formulation is further formulated in to the fast disintegrating tablets (FDT) by using superdisintegrants. So that after taking such a tablets, the tablet only disintegrates into the mouth then microspheres are separated and ingestion of such microspheres starts releasing drug for prolonged period of time. This concept fulfills both the advantages of sustained release and fast disintegrating tablets. Diclofenac Sodium is recommended in the Osteoarthritis, rheumatoid arthritis, and Spondylitis. It's administered in the doses of 75-150 mg daily in divided doses.

\section{MATERIALS AND METHODS}

\section{Materials:}

Diclofenac Sodium was obtained as a gift sample from Arati Drugs Ltd, Mumbai, India. Microcrystalline cellulose (Avicel), magnesium stearate, sodium alginate and calcium chloride were purchased from Loba Chemie Mumbai, India. Crospovidone, sodium starch glycolate and mannitol were purchased from Molychem, Mumbai. All chemicals used were of analytical reagent grade and double distilled water was used throughout the experiments.

\section{Methods:}

\section{Preparation of Microspheres}

Microspheres are prepared by Ionotropic gelation technique. Here, required amount of carbopol was dispersed in a specified volume of cold water containing the drug and allowed to swell for 23 hours. In another beaker suitable amount of sodium alginate was taken and mixed well with specified volume of water. The carbopol solution containing the drug was added to sodium alginate solution with stirring to produce a viscous form. Then polymer drug solution was added drop wise by using syringe of $21 \mathrm{G}$ in diameter from a height of about $5 \mathrm{~cm}$ into a beaker containing $4 \% \mathrm{w} / \mathrm{v}$ solution of calcium chloride with continuous stirring by magnetic stirrer (Figure1). Then the solution containing the gel formed microspheres was filtered by using Whatman filter paper No-1. The microspheres were allowed to dry at about 30 to $40^{\circ} \mathrm{C}$ for $2-3$ days and stored in well-closed container for further use (Table 1) [8, 9]. 


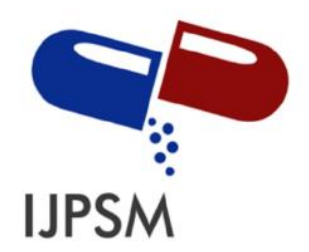

Lukkad Harish R et al, Int. Journal of Pharmaceutical Sciences and Medicine (IJPSM), Vol.6 Issue. 4, April- 2021, pg. 52-66

ISSN: 2519-9889

Impact Factor: $\mathbf{3 . 4 2 6}$

\section{Evaluation of Microspheres}

\section{Particle Size Analysis}

Particle size of all batches of microspheres were determined by using Digital microscope.

\section{Drug entrapment efficiency and drug loading}

The amount of Diclofenac Sodium present in the microspheres was determined by taking the known amount of microspheres in which $100 \mathrm{mg}$ of drug should be present theoretically. Then the microspheres ware crushed and the powdered microspheres was taken and dissolved in 100 $\mathrm{ml}$ of phosphate buffer ( $\mathrm{pH} 7.4)$ solution and stirred for $15 \mathrm{~min}$ with an interval of 5 min and allowed to keep for 24 hrs. Then the solution was filtered through Whatman No.1 filter paper. Then the absorbance was measured spectrophotometrically and concentrations were determined by employing simultaneous equation: $\mathrm{Y}=\mathrm{mx}+\mathrm{c}$

Drug Entrapment Efficiency $(\%)=$ [Experimental drug Content/ Initial Drug Content into the Formulation] $\times 100$

Drug Loading $(\%)=[\mathrm{Qm} / \mathrm{Wm}] \times 100$,

Where, $\mathrm{Wm}=$ weight of the microspheres; $\mathrm{Qm}=$ quantity of the drug present in the microspheres.

\section{Swelling study (Degree of swelling)}

Microspheres (50 mg) were placed in little excess of distilled water, $0.1 \mathrm{~N} \mathrm{HCl}$ and PBS (pH 7.4) and allowed to swell to constant weight. The microspheres were removed, blotted with filter paper and their changes in weight were measured at an interval period of $10 \mathrm{~min}$ and recorded. The degree of swelling (a) was then calculated from the formula: $\mathrm{a}=\mathrm{W}_{\mathrm{G}}-\mathrm{W}_{\mathrm{O}} / \mathrm{W}_{\mathrm{O}}$

Where, Wo is the initial weight of the microspheres and $\mathrm{W}_{\mathrm{G}}$ is the weight of the microspheres at equilibrium swelling in the medium. 


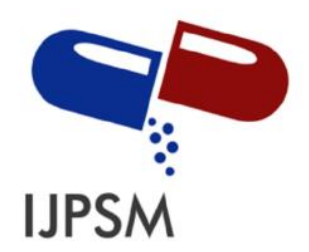

Lukkad Harish R et al, Int. Journal of Pharmaceutical Sciences and Medicine (IJPSM), Vol.6 Issue. 4, April- 2021, pg. 52-66

ISSN: 2519-9889

Impact Factor: $\mathbf{3 . 4 2 6}$

\section{In vitro release study}

The dissolution process was carried out in USP dissolution rate test apparatus [Apparatus-II (paddle method), $75 \mathrm{rpm}, 37 \pm 0.5^{0} \mathrm{C}$ ] taking microspheres equivalent to $100 \mathrm{mg}$ Diclofenac Sodium in $900 \mathrm{ml}$ of $2 \%$ SLS in $0.1 \mathrm{~N} \mathrm{HCl}$ media for first $2 \mathrm{hrs}$, followed by $900 \mathrm{ml} 1 \%$ SLS in $\mathrm{pH} 6.8$ phosphate buffer for next $10 \mathrm{hrs}$. The media of $\mathrm{pH} 1.2(0.1 \mathrm{~N} \mathrm{HCl})$ was chosen to represent the gastric condition; $\mathrm{pH} 6.8$ was a compromise condition between the $\mathrm{pH}$ of the gastric and small intestine. Aliquots samples were withdrawn for cumulative drug release at specified time intervals and replaced with same volume of fresh media, filtered and analyzed spectrophotometrically. [10-12].

\section{Formulation of tablets}

Fast disintegrating tablets were prepared using super disintegrants addition. Different ratio of microcrystalline cellulose and superdisintegrant were used. The ratio giving the best disintegration time along with optimum hardness was chosen and tablets prepared by direct compression. Accurately weighed microspheres were properly mixed with Microcrystalline Cellulose, Superdisintegrant and Mannitol for about 10-15 min. Then magnesium stearate was added and mixed for further 2 min and compressed into tablets (Table 2).

\section{Evaluation of the tablets}

The prepared tablets were evaluated for thickness, weight variation, hardness, friability, drug content, wetting time, disintegration time and In-vitro dissolution time as per the official methods.

\section{Thickness}

The thickness of the tablets was determined using a Vernier caliper. 


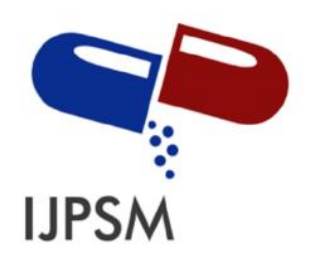

Lukkad Harish R et al, Int. Journal of Pharmaceutical Sciences and Medicine (IJPSM), Vol.6 Issue. 4, April- 2021, pg. 52-66

ISSN: 2519-9889

Impact Factor: 3.426

\section{Weight variation}

Randomly, twenty tablets were selected after compression and the mean weight was determined using an electronic balance. None of the tablets deviated from the average weight by more than $\pm 5 \%$.

\section{Hardness}

The crushing strength of the tablets was measured using a Pfizer hardness tester.

\section{Friability}

Ten tablets were weighed and placed in a Roche friabilator and the equipment was rotated at 25 rpm for $4 \mathrm{~min}$. The tablets were taken out, dedusted and reweighed. The percentage friability of the tablets was measured as per the following formula,

$$
\text { Percentage friability }=\frac{\text { Initial weight }- \text { Final weight }}{\text { Initial weight }} \times 100
$$

\section{Drug content}

The tablet from each formulation was crushed and powdered material was taken. Then dissolved in $100 \mathrm{ml}$ phosphate buffer ( $\mathrm{pH} \mathrm{7.4)} \mathrm{solution} \mathrm{and} \mathrm{stirred} \mathrm{for} 15 \mathrm{~min}$ with an interval of 5 min and allowed to keep for $24 \mathrm{hrs}$ with occasional stirring. Then the solution was filtered through Whatman No.1 filter paper. Then the absorbance was measured spectrophotometrically against phosphate buffer ( $\mathrm{pH}$ 7.4) solution as blank with the help of UV spectrophotometer and concentrations were determined by employing simultaneous equation: $Y=m x+c$. Three tablets from each formulation batch were tested randomly and the average reading noted.

\section{Wetting time}

A piece of tissue paper $(12 \mathrm{~cm} \times 10.75 \mathrm{~cm})$ folded twice was placed in a Petri dish (Internal Diameter $=9 \mathrm{~cm}$ ) containing $9 \mathrm{ml}$ of buffer solution simulating saliva $\mathrm{pH} 6.8$. A tablet was placed on the paper and the time taken for complete wetting was noted. Three tablets from each formulation were randomly selected and the average wetting time was noted. 


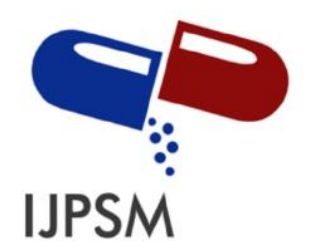

Lukkad Harish R et al, Int. Journal of Pharmaceutical Sciences and Medicine (IJPSM), Vol.6 Issue. 4, April- 2021, pg. 52-66

ISSN: 2519-9889

Impact Factor: $\mathbf{3 . 4 2 6}$

\section{In vitro disintegration time}

The disintegration time for all formulations was carried out using tablet disintegration test apparatus. Six tablets were placed individually in each tube of disintegration test apparatus and discs were placed. The phosphate buffer $\mathrm{pH} 6.8$ was used as a medium and temperature of $37^{\circ} \pm 2^{\circ} \mathrm{C}$ was maintained. The time taken for the entire tablet to disintegrate completely was noted.

\section{In vitro release study}

The dissolution process was carried out in USP dissolution rate test apparatus [Apparatus-II (paddle method), $75 \mathrm{rpm}, 37 \pm 0.5^{0} \mathrm{C}$ ] taking prepared tablet of Diclofenac Sodium in $900 \mathrm{ml}$ of $2 \%$ SLS in $0.1 \mathrm{~N} \mathrm{HCl}$ media for first $2 \mathrm{hrs}$, followed by $900 \mathrm{ml} 1 \%$ SLS in pH 6.8 phosphate buffer for next $10 \mathrm{hrs}$. The media of $\mathrm{pH} 1.2(0.1 \mathrm{~N} \mathrm{HCl})$ was chosen to represent the gastric condition; $\mathrm{pH} 6.8$ was a compromise condition between the $\mathrm{pH}$ of the gastric and small intestine. Aliquots samples were withdrawn at specified time intervals and replaced with same volume of fresh media, filtered and analyzed spectrophotometrically for cumulative drug release [14-16].

\section{RESULTS AND DISCUSSION}

\section{Evaluation of Microspheres}

\section{Particle Size Analysis}

Particle size can be determined by using Digital microscope. The mean diameter of Diclofenac Sodium microspheres was found in between $79.36 \pm 0.43$ to $90.20 \pm 0.34 \mu \mathrm{m}$ (Table 3).

\section{Drug entrapment efficiency and drug loading}

The percent encapsulation efficiency was increased upto $80.4 \pm 0.26 \%$ with increasing polymer concentration (Table 4).

\section{Swelling study (Degree of swelling)}

Prepared microspheres swell in distilled water, $0.1 \mathrm{~N} \mathrm{HCl}$ and phosphate buffer 6.8 (Table 5). 


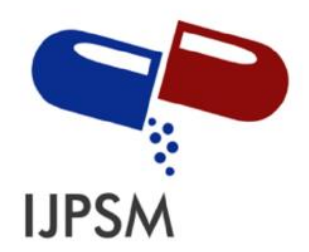

Lukkad Harish R et al, Int. Journal of Pharmaceutical Sciences and Medicine (IJPSM), Vol.6 Issue. 4, April- 2021, pg. 52-66

ISSN: 2519-9889

Impact Factor: $\mathbf{3 . 4 2 6}$

\section{In vitro drug release study}

The dissolution process was carried out in USP dissolution rate test apparatus [Apparatus-II (paddle method), $75 \mathrm{rpm}, 37 \pm 0.5^{0} \mathrm{C}$ ] taking microspheres equivalent to $100 \mathrm{mg}$ Diclofenac Sodium in $900 \mathrm{ml}$ of $2 \%$ SLS in $0.1 \mathrm{~N} \mathrm{HCl}$ media for first 2 hours, followed by $900 \mathrm{ml} 1 \%$ SLS in pH 6.8 phosphate buffer for next 10 hours. (Figure 2).

\section{Formulation of tablets}

Among all the formulations of microspheres F1 to F7, F7 shows good mean particle size, drug entrapment efficiency, drug loading, degree of swelling and good In-Vitro drug release data. So, F7 formulation was chosen for the preparation of the fast disintegrating tablets.

\section{Evaluation of the tablets}

In the present study fast disintegrating tablets of Diclofenac Sodium microspheres were prepared by using Crospovidone and Sodium starch glycolate as a superdisintegrants. Total numbers of six formulations were prepared by direct compression technique. The data obtained of postcompression parameters such as thickness, weight variation, hardness, friability, amount of drug content, wetting time and in-vitro disintegration time are shown in (Table $6 \& 7$ ).

\section{In vitro release study}

In vitro dissolution studies of various formulations at the end of 12 hours are reported. (Figure 3).

\section{CONCLUSION}

The present study demonstrated the successful preparation of stable, sustained release fast disintegrating tablets of Diclofenac Sodium. It is a totally new concept. As such the sustained release tablets are able to maintain steady drug plasma levels for extended periods of time, reduced total dose, improved efficiency in treatment as a result the variations of the drug levels in the blood are prevented and minimized drug related side effects. But many patients like paediatric, geriatric and also patients may have difficulty in swallowing (Dysphagia) find it 


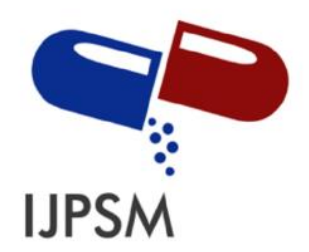

Lukkad Harish R et al, Int. Journal of Pharmaceutical Sciences and Medicine (IJPSM), Vol.6 Issue. 4, April- 2021, pg. 52-66

ISSN: 2519-9889

Impact Factor: 3.426

difficult to swallow tablets and thus do not comply with prescription. This problem is overcome by formulating and developing sustained release fast disintegrating tablets. This concept fulfills both the advantages of sustained release and fast disintegrating tablets.

Among all the formulations of microspheres, F7 formulation shows good mean particle size, drug entrapment efficiency, drug loading, degree of swelling and good In-Vitro drug release data. So, F7 formulation was chosen for the preparation of the fast disintegrating tablets. Among all the formulations tablets, batch S3 containing SSG (4\%) was found to be the best as compare to other formulations as this formulation showed good hardness, low friability and least wetting time \& disintegration time.

\section{ACKNOWLEDGEMENTS}

The authors are thankful to Arati Drugs Ltd, Mumbai, India for providing the gift sample of Diclofenac Sodium. The authors wish to thanks Dr. Rajesh Oswal for proper guidance and full support.

\section{REFERENCES}

[1]. Brahma N Singh, Kwon H Kim, "Drug delivery- Oral route” Encyclo, Pharma. Tech; 886- 889 (2002).

[2]. Yie W. Chein "Oral drug delivery and delivery systems” 2nd edn Marcel Dekker- Inc, New-york; 139 (1992).

[3]. Jantzen GM, Robinson JR. Sustained and controlled drug delivery systems. In: Banker GS, Rhodes CT (Eds). Modern Pharmaceutics. 3rd edition. New York, Marcel Dekker Inc., 576-593 (1996).

[4]. Patric B. Deasy "Microencapsulation and related drug process" Drugs and pharmaceutical Science, 2nd edn, Marcel Dekker Inc, Newyork; 1-22 (1984).

[5]. Prasanth v.v, Akash Chakraborthy Moy, Sam T Mathew, Rinku Mathapan. Microspheres - An Overview. Int. J. of Res. in Pharm. and Biomed. Sci. Vol. 2 (2): 332-338 (Apr - Jun 2011).

[6]. Suresh Bhandari, Rajender Kumar Mittapalli, Ramesh Gannu, Yamsani Madhusudhan Rao. Orodispersible tablets: An overview. Asian J. of Pharmaceutics.2-11 (January 2008).

[7]. Anthony C Moffat, M. David Osselton \& Brian Widdop. Clark's Analysis of Drugs \& Poisons. $3^{\text {rd }}$ Edition. Vol 2: 570,571. 


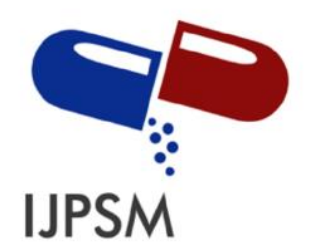

Lukkad Harish R et al, Int. Journal of Pharmaceutical Sciences and Medicine (IJPSM), Vol.6 Issue. 4, April- 2021, pg. 52-66

ISSN: 2519-9889 Impact Factor: $\mathbf{3 . 4 2 6}$

[8]. R. mazumder, L. K. Nath, A. Haque, T. Maity, P. K. Choudhury, B. Shrestha, M. Chakraborty, R. N. Pal. Formulation and In-vitro evaluation of natural polymers based microspheres for colonic drug delivery. Int. J. of Pharmacy and Pharm. Sci. Vol- 2, Issue 1: 211-220 (2010).

[9]. Chudhury PK, Kar M. Preparation of alginate beads containing Metformin $\mathrm{HCl}$ using EmulsionGelation method. Trop. J. Pharma. Res. 4(2): 489-493(2005).

[10].Du J, Dai J, Liu JL, Dankovich T, Novel pH-sensitive polyelectrolyte carboxymethyl Konjac glucomannan- chitosan beads as drug carriers, Funct Polym, 66, 1055-1061, 2006.

[11].Pawlak A, Mucha M, Thermogravimetric and FTIR studies of chitosan blends, Thermochim Acta, 396, 153-166,( 2003).

[12].Friedrich $\mathrm{H}$, Bodmeier N: Solid state and dissolution rate characterization of nifedipine and hydrophilic carriers, Drug Delivery and Industrial Pharmacy; 31: 719 - 728 (2005).

[13].Preeti Karwa, P. V. Kasture. (2011). Preparation and characterization of dual release Tablet for Zolpiderm . International J. for PharmTech Res.. 3(IV): 1919-1929.

[14].Lachman L, Lieberman HA, Kanig JL. The Theory and Practice of Industrial Pharmacy; Philadelphia, PA: Lea and Febiger; 317-318 (1987).

[15].Patel H.P. (2011). A new approach for preparation of Zolpidem tablets that releases drug slowly and for long time: Int. J. of Pharma. Sci.., 7(2): 53-58.

[16].Pharmacopoeia of India. New Delhi: Ministry of Health and Family Welfare, Government of India, Controller of Publications; 175-183 (2007).

Table 1: Formulations of microspheres

\begin{tabular}{|c|c|c|c|c|c|}
\hline $\begin{array}{c}\text { Code } \\
\text { of } \\
\text { Formulation }\end{array}$ & Drug & $\begin{array}{c}\text { Polymer } \\
\text { Carbopol } \\
(\mathbf{m g})\end{array}$ & $\begin{array}{c}\text { Sod. Alginate } \\
(\mathbf{m g})\end{array}$ & $\begin{array}{c}\text { Carbopol + Sod. } \\
\text { alginate } \\
(\mathbf{m g})\end{array}$ & $\begin{array}{c}\text { Drug: } \\
\text { Polymer } \\
\text { Ratio }\end{array}$ \\
\hline F1 & 100 & 0 & 100 & 100 & $1: 1$ \\
\hline F2 & 100 & 0 & 200 & 200 & $1: 2$ \\
\hline F3 & 100 & 0 & 300 & 300 & $1: 3$ \\
\hline F4 & 100 & 0 & 400 & 400 & $1: 4$ \\
\hline F5 & 100 & 100 & 100 & 200 & $1: 2$ \\
\hline F6 & 100 & 200 & 100 & 300 & $1: 3$ \\
\hline F7 & 100 & 300 & 100 & 400 & $1: 4$ \\
\hline
\end{tabular}




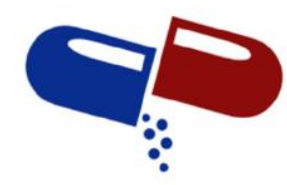

IJPSM

Lukkad Harish R et al, Int. Journal of Pharmaceutical Sciences and Medicine (IJPSM),

Vol.6 Issue. 4, April- 2021, pg. 52-66

ISSN: 2519-9889

Impact Factor: 3.426

Table 2: Formulation of FDT of Diclofenac Sodium

\begin{tabular}{|c|l|c|c|c|c|c|c|}
\hline \multirow{2}{*}{ Sr. No. } & \multirow{2}{*}{ Ingredients } & \multicolumn{6}{|c|}{ Formulations } \\
\cline { 3 - 8 } & & S1 & S2 & S3 & S4 & S5 & S6 \\
\hline 1 & Microspheres & 250 & 250 & 250 & 250 & 250 & 250 \\
\hline 2 & SSG & 6 & 9 & 12 & 6 & 9 & 12 \\
\hline 3 & Mannitol & 15 & 15 & 15 & 15 & 15 & 15 \\
\hline 4 & MCC & 121.5 & 118.5 & 115.5 & 121.5 & 118.5 & 115.5 \\
\hline 5 & Magnesium stearate & 7.5 & 7.5 & 7.5 & 7.5 & 7.5 & 7.5 \\
\hline & Total weight (mg) & 400 & 400 & 400 & 400 & 400 & 400 \\
\hline
\end{tabular}

Table 3: Mean particle size of microspheres

\begin{tabular}{|c|c|c|}
\hline Sr. No. & Formulation code & Mean Particle size $(\boldsymbol{\mu m})$ \\
\hline 1 & F1 & $84.28 \pm 0.68$ \\
\hline 2 & F2 & $82.12 \pm 0.22$ \\
\hline 3 & F3 & $80.40 \pm 0.46$ \\
\hline 4 & F4 & $79.36 \pm 0.43$ \\
\hline 5 & F5 & $84.32 \pm 0.32$ \\
\hline 6 & F6 & $90.20 \pm 0.34$ \\
\hline 7 & F7 & $89.33 \pm 0.54$ \\
\hline
\end{tabular}




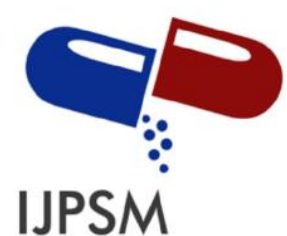

Lukkad Harish R et al, Int. Journal of Pharmaceutical Sciences and Medicine (IJPSM), Vol.6 Issue. 4, April- 2021, pg. 52-66

ISSN: 2519-9889 Impact Factor: $\mathbf{3 . 4 2 6}$

Table 4: Drug entrapment efficiency and Drug loading of microspheres

\begin{tabular}{|c|c|c|c|}
\hline Sr. No. & Formulation code & DEE (\%) & DL (\%) \\
\hline 1 & F1 & $48.44 \pm 0.66$ & $24.22 \pm 0.33$ \\
\hline 2 & F2 & $52.6 \pm 0.36$ & $26.3 \pm 0.18$ \\
\hline 3 & F3 & $56.8 \pm 0.72$ & $28.4 \pm 0.36$ \\
\hline 4 & F4 & $64.48 \pm 0.40$ & $32.24 \pm 0.2$ \\
\hline 5 & F5 & $68.90 \pm 0.48$ & $34.45 \pm 0.24$ \\
\hline 6 & F6 & $74.64 \pm 0.44$ & $37.32 \pm 0.22$ \\
\hline 7 & F7 & $80.4 \pm 0.26$ & $40.2 \pm 0.13$ \\
\hline
\end{tabular}

Table 5: Swelling study of prepared microspheres

\begin{tabular}{|c|c|c|c|c|}
\hline \multirow{2}{*}{ Sr. No. } & Formulation & \multicolumn{3}{|c|}{ Degree of swelling } \\
\cline { 3 - 5 } & & 0.1 N HCL & Distilled water & Phosphate buffer 6.8 \\
\hline 1 & F1 & 0.27 & 0.42 & 0.82 \\
\hline 2 & F2 & 0.33 & 0.49 & 0.96 \\
\hline 3 & F3 & 0.34 & 0.55 & 1.13 \\
\hline 4 & F4 & 0.45 & 0.61 & 1.25 \\
\hline 5 & F5 & 0.54 & 0.70 & 1.30 \\
\hline 6 & F6 & 0.64 & 0.79 & 1.41 \\
\hline 7 & F7 & 0.71 & 0.98 & 1.58 \\
\hline
\end{tabular}




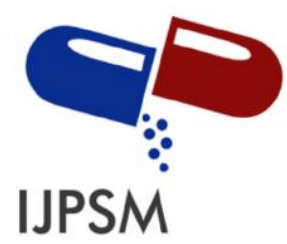

Lukkad Harish R et al, Int. Journal of Pharmaceutical Sciences and Medicine (IJPSM), Vol.6 Issue. 4, April- 2021, pg. 52-66

ISSN: 2519-9889 Impact Factor: 3.426

Table 6: Evaluation of the tablets (S1, S2, S3)

\begin{tabular}{|c|l|c|c|c|}
\hline \multirow{2}{*}{ Sr. No. } & \multicolumn{1}{|c|}{ Evaluation parameters } & \multicolumn{3}{|c|}{ Formulations } \\
\cline { 3 - 5 } & & S1 & S2 & S3 \\
\hline 1 & Thickness (mm) & 4.6 & 4.6 & 4.6 \\
\hline 2 & Weight variation $(\mathrm{mg})$ & 398.58 & 400.2 & 399.4 \\
\hline 3 & Hardness $\left(\mathrm{kg} / \mathrm{cm}^{2}\right)$ & $4.2 \pm 0.6$ & $4.6 \pm 0.4$ & $4.5 \pm 0.2$ \\
\hline 4 & Friability (\%) & $0.72 \pm 0.4$ & $0.74 \pm 0.36$ & $0.56 \pm 0.4$ \\
\hline 5 & Drug content $(\%)$ & $99.7 \pm 0.2$ & $100.1 \pm 0.3$ & $100.2 \pm 0.2$ \\
\hline 6 & Wetting time (sec) & $44.3 \pm 1.6$ & $42.3 \pm 2.4$ & $39.2 \pm 2.1$ \\
\hline 7 & In- vitro disintegration time $(\mathrm{sec})$ & $66.2 \pm 2.1$ & $58.4 \pm 2.2$ & $51.2 \pm 1.8$ \\
\hline
\end{tabular}

Table 7: Evaluation of the tablets (S4, S5, S6)

\begin{tabular}{|c|l|c|c|c|}
\hline \multirow{2}{*}{ Sr. No. } & \multicolumn{1}{|c|}{ Evaluation parameters } & \multicolumn{3}{c|}{ Formulations } \\
\cline { 3 - 5 } & & S4 & S5 & S6 \\
\hline 1 & Thickness (mm) & 4.6 & 4.6 & 4.6 \\
\hline 2 & Weight variation (mg) & 399.08 & 401.44 & 400.6 \\
\hline 3 & Hardness (kg/cm $\left.{ }^{2}\right)$ & $4.2 \pm 0.3$ & $4.4 \pm 0.7$ & $4.6 \pm 0.8$ \\
\hline 4 & Friability (\%) & $0.66 \pm 0.09$ & $0.56 \pm 0.24$ & $0.67 \pm 0.4$ \\
\hline 5 & Drug content (\%) & $99.8 \pm 0.2$ & $100.0 \pm 0.4$ & $99.8 \pm 0.3$ \\
\hline 6 & Wetting time (sec) & $64.2 \pm 1.6$ & $60.1 \pm 0.8$ & $54.8 \pm 1.3$ \\
\hline 7 & In- vitro disintegration time (sec) & $80.4 \pm 1.6$ & $73.1 \pm 1.5$ & $62.1 \pm 2.0$ \\
\hline
\end{tabular}




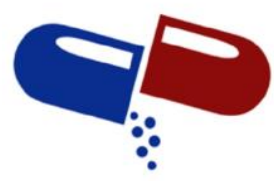

IJPSM

Lukkad Harish R et al, Int. Journal of Pharmaceutical Sciences and Medicine (IJPSM), Vol.6 Issue. 4, April- 2021, pg. 52-66

ISSN: 2519-9889

Impact Factor: 3.426

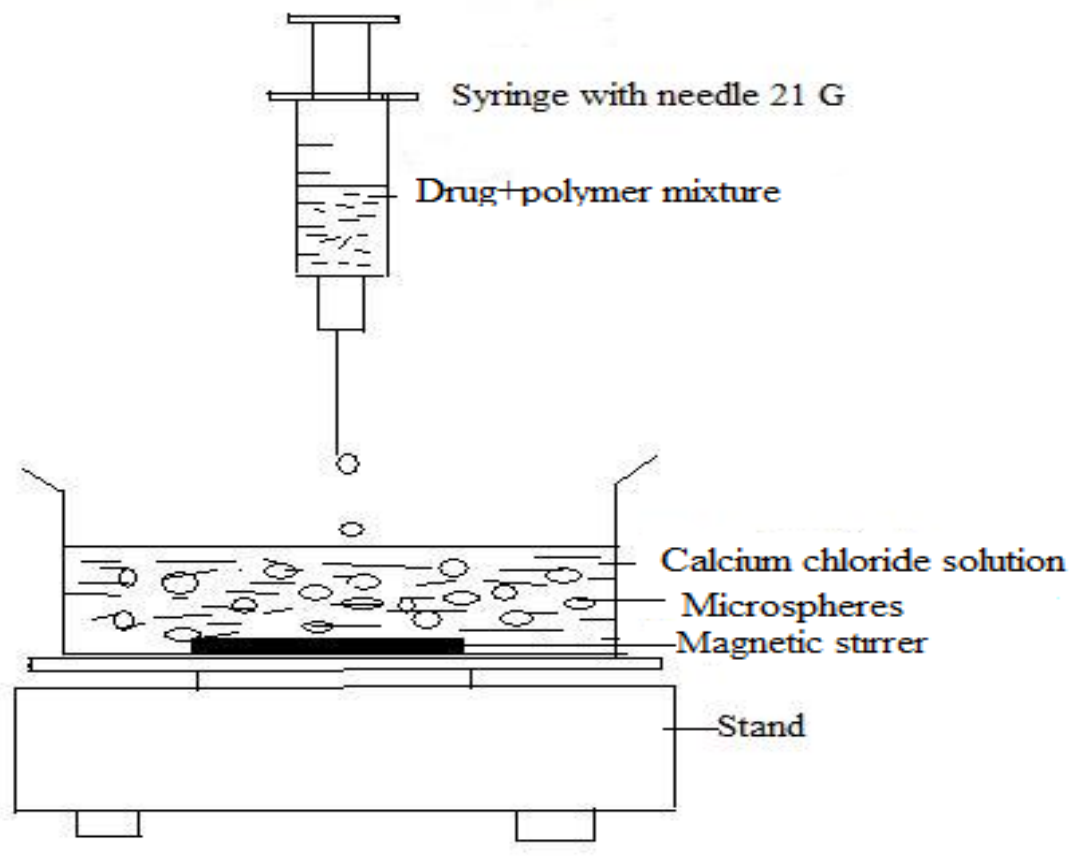

Figure1: Ionic gelation technique

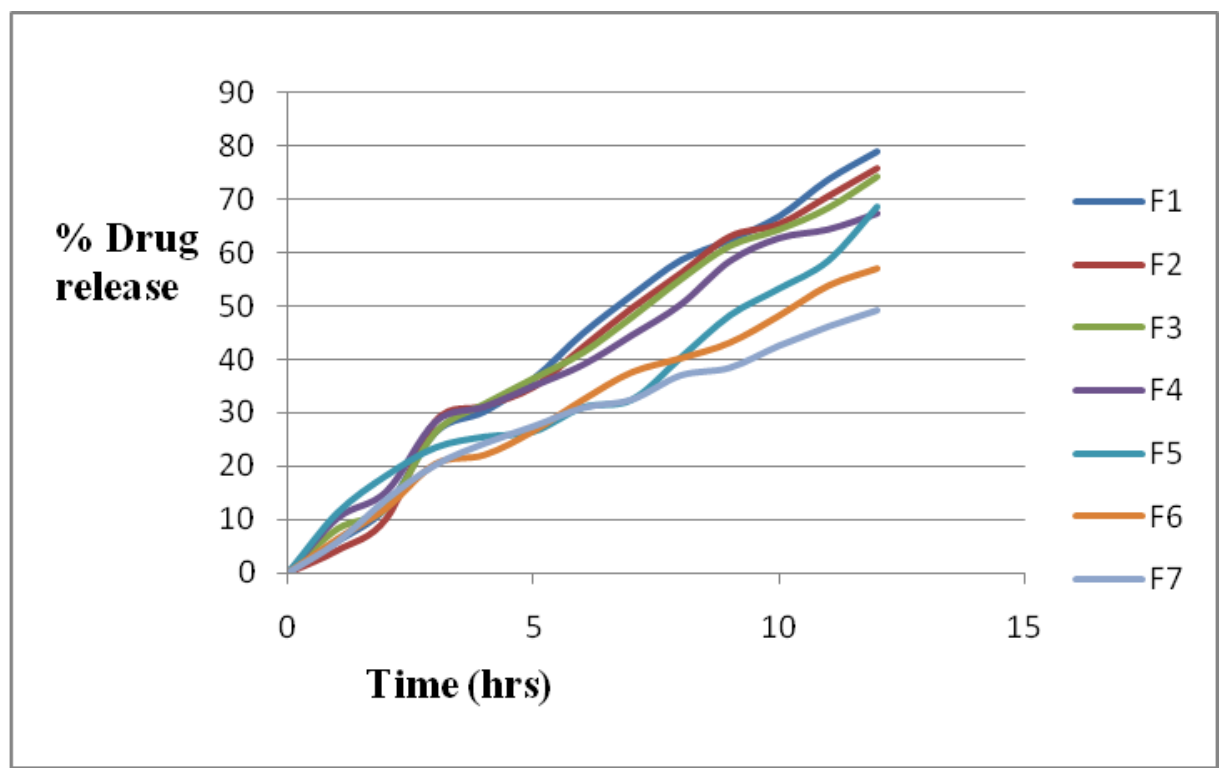

Figure 2: In vitro drug release study of prepared microspheres 


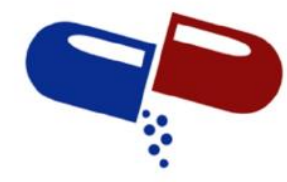

IJPSM

Lukkad Harish R et al, Int. Journal of Pharmaceutical Sciences and Medicine (IJPSM), Vol.6 Issue. 4, April- 2021, pg. 52-66

ISSN: 2519-9889

Impact Factor: 3.426

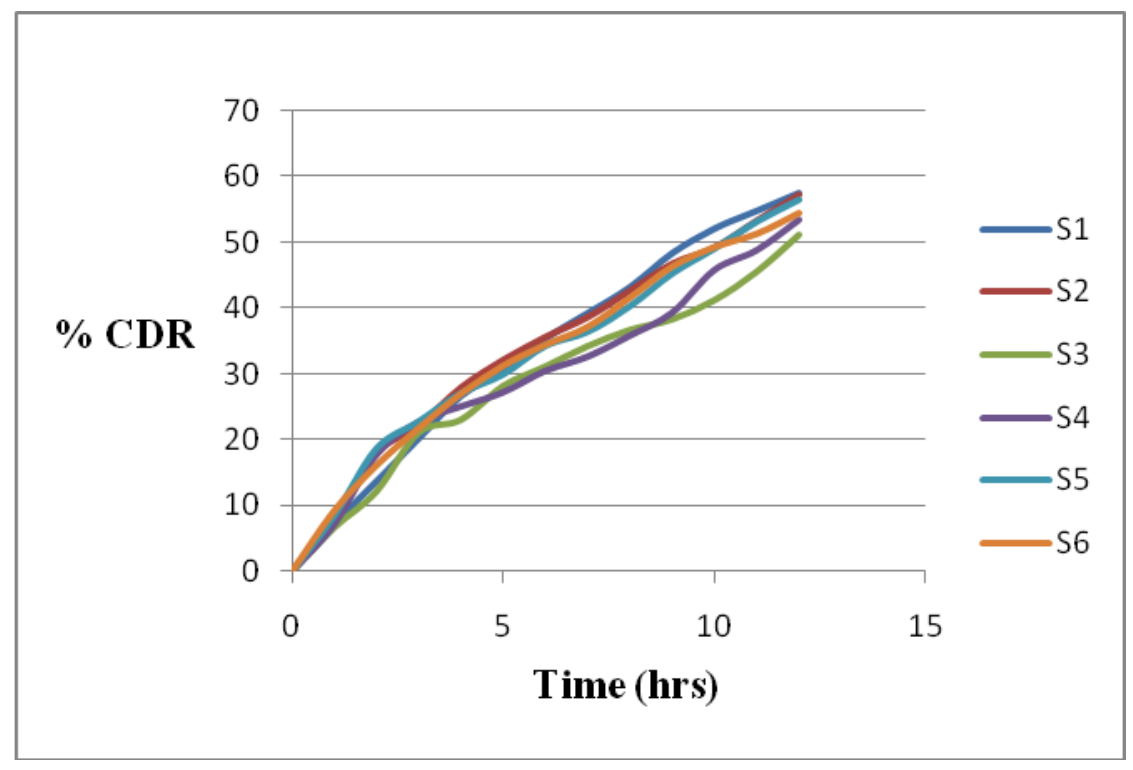

Figure 3: In vitro drug release study of the tablets 